\title{
LET'S (NOT) MAKE THIS WORK! WHY STARE DECISIS WORKABILITY SHOULD BE A SWORD BUT NOT A SHIELD
}

Audrey J. Lynn

INTRODUCTION

Anyone who has studied the modern doctrine of stare decisis is probably familiar with the term workability. A factor of the United States Supreme Court's stare decisis test, workability differentiates precedential rules that have proven easy for lower courts to apply in a consistent and fair manner from those that have not. ${ }^{1}$ The former are said to be workable, the latter, unworkable. Because one of the principal justifications for stare decisis is that it "promotes the evenhanded, predictable, and consistent development of legal principles," ${ }^{2}$ workability seems like a perfunctory consideration: surely if the goal is to have a smooth-functioning system, it makes sense to retain workable rules and purge those that turn out Gordian. But this seemingly innocuous principle may be quite sinister if applied incautiously, threatening the structural integrity of the very system it is meant to support.

This Note was inspired by a decision rendered by the Supreme Court of Georgia during the summer of $2017 .^{3}$ The case was quite tame on the surface-no crime, no intrigue, just a dispute with a city over a zoning map, resolution of which had been temporarily delayed by an

1 “"[T] he workability factor considers the ability of lower courts to apply the holding of a previous decision. An unworkable rule causes 'inherent confusion' or 'poses a direct obstacle to the realization of important objectives embodied in other laws." 'David L. Berland, Stopping the Pendulum: Why Stare Decisis Should Constrain the Court from Further Modification of the Search Incident to Arrest Exception, 2011 U. ILL. L. REV. 695, 702 (2011) (quoting Patterson v. McLean Credit Union, 491 U.S. 164, 173 (1989)).

2 Payne v. Tennessee, 501 U.S. 808, 827 (1991). See 3-30 MoOrE's MANUAL-FEDERAL PRACTICE AND PROCEDURE $\$ 30.10$ (2017) for a description of the general purposes of stare decisis.

${ }^{3}$ Schumacher v. City of Roswell, 803 S.E.2d 66 (Ga. 2017). 
unplanned trip to the high court regarding a matter of appellate procedure. ${ }^{4}$ Hardly the stuff of legend. But within the context of this rather prosaic local dispute there lurked a question of far more dramatic and wide-ranging consequence: just whose responsibility is it to make sure law works? When a court comes to understand that applicable precedent is wrong as a misinterpretation of a statute (or for that matter, a constitution), but the more faithful interpretation is deficient, causes headaches for the judicial system, nightmares for litigants and attorneys, inefficiencies, dismissals without decisions on the merits, and other undesirable outcomes, should the court preserve the erroneous but essentially better rule under stare decisis? In short, is the workability of precedent a legitimate reason for retaining it?

This would seem to be a question that experts in jurisprudence would have resolved centuries ago, but apparently very few authors have discussed it. There is, of course, no shortage of discourse on the doctrine of stare decisis in general, or even on workability as a stare decisis consideration. But, owing perhaps to the lack of a clear signal from the United States Supreme Court (as discussed below), authors almost universally overlook the functional distinction between the use of unworkability as a reason for discarding precedent and the use of workability as a reason for retaining it. The distinction, however, is vital.

This Note will begin by explaining the case that gave rise to it. This will provide readers with a concrete example of what this Note will sometimes refer to as the "preservative use" of workability. The Note will then lay out the history of workability as a consideration of stare decisis and describe how the factor has changed in recent decades. In so doing, its focus will be on workability in the context of statutory interpretation. In order to explain the background and development of the factor, however, it will be necessary to discuss specific cases in which the Supreme Court has applied workability in the context of constitutional interpretation. The two

\footnotetext{
${ }^{4} I d$. at 68 .
} 
contexts must be differentiated for purposes of this Note because the thesis of this Note-i.e., that preserving an incorrect interpretation of a statute because of its relative workability violates separation of powers - has no parallel when a court interprets a constitution because in that case there is no inherent infringement on legislative power. This Note will then explain why the change toward using workability to preserve erroneous precedent is not required logically, contravenes the basic purposes of stare decisis, and is constitutionally invalid as a violation of separation of powers. Finally, this Note will propose a new way to articulate the stare decisis test that does not discard workability as a consideration but precludes the preservative use criticized by this Note.

\section{BACKGROUND}

\section{A. Inspiration and Illustration}

Schumacher v. City of Roswell involved a facial challenge to a new zoning map the City recently had drawn up. ${ }^{5}$ The invalidity of the ordinance under the Constitution of the State of Georgia was the sole claim presented. ${ }^{6}$ Because their claim was that the ordinance violated the State's constitution, the plaintiffs took their case directly to a state superior (trial) court. ${ }^{7}$ No aspect of the plaintiff's case was ever reviewed by the City or any administrative body. ${ }^{8}$ The trial court ruled against the plaintiffs on the merits. ${ }^{9}$ The plaintiffs then filed a "direct appeal" with the Court of Appeals of Georgia, ${ }^{10}$ the intermediate appellate court. That court dismissed the appeal for lack of jurisdiction, believing that the appellants were, under the circumstances,

\footnotetext{
${ }^{5} I d$.

${ }^{6} \mathrm{Id}$.

${ }^{7} I d$.

${ }^{8} I d$. at 68-69 ("There was no individualized determination by any level of city government.”).

${ }^{9} I d$. at 68 .

${ }^{10} I d$.
} 
required by law to comply with the application procedures for discretionary appeals. ${ }^{11}$ The Georgia Supreme Court granted certiorari on this issue. ${ }^{12}$

Relevant precedent required that "all zoning cases" be appealed via the discretionary route, rather than by direct appeal. ${ }^{13}$ While the majority ultimately concluded that the precedent was simply inapplicable and reversed the Court of Appeals, ${ }^{14}$ the dissent believed relevant case law was on point and, regardless of whether it represented the most accurate interpretation of the applicable statutes, should apply because of stare decisis considerations. ${ }^{15}$ Foremost among these considerations was workability. ${ }^{16}$ Ostensibly, the "all zoning cases" rule was straightforward and easy to apply. ${ }^{17}$ If the underlying subject matter is zoning, appellants must use the discretionary appeals process. ${ }^{18}$ The applicable statutes, however, said nothing about "zoning cases," but instead mandated that the discretionary process be employed for any appeal taken from a

${ }^{11} I d$. There are two types of appeals that may be filed under Georgia law: direct appeals and appeals by application (otherwise known as discretionary appeals). Two code sections, O.C.G.A. § 5-6-34 and O.C.G.A. § 5-635 , specify the types of rulings to which each procedure applies. Code Section 5-6-34, providing for direct appeals, applies in pertinent part to "[a]11 judgments or orders granting or refusing applications for receivers or for interlocutory or final injunctions" and "[a]ll final judgments, that is to say, where the case is no longer pending in the court below, except as provided in Code Section 5-6-35." GA. CoDE. ANN. § 5-6-34(a)(1), (4) (2017). When a direct appeal is properly filed, "all judgments, rulings, or orders rendered in the case which are raised on appeal and which may affect the proceedings below shall be reviewed and determined by the appellate court ...." § 5-6-34(d). In contrast, Section 5-6-35, which covers appeals by application, allows for a more expeditious appeals process in certain cases. This section was ostensibly designed to ease appellate courts' case load. See Scruggs v. Georgia Dep't of Human Res., $408 \quad$ S.E.2d 103, $103 \quad$ (1991) (explaining that "[t]he discretionary-application statute, O.C.G.A. § 5-6-35, was enacted to ameliorate the appellate courts' massive case loads"); Tri-State Bldg. \& Supply, Inc. v. Reid, 302 S.E.2d 566, 567-68 (1983) (referring to "the clear purpose of O.C.G.A. $\S 5-6-35$ to permit the appellate courts to expeditiously review decisions of the superior courts reviewing decisions of administrative agencies without issuing an opinion in every such case"). It requires only that the reviewing court "issue an order granting or denying such an appeal within 30 days of the date on which the application was filed." $§ 5-6-35(\mathrm{f})$. As it pertains to Schumacher, Section 5-6-35 provides that "[a]ppeals from decisions of the superior courts reviewing decisions . . . state and local administrative agencies" must be by application. § 5-6-35(a)(1); 803 S.E.2d at 68-69.

${ }^{12}$ Schumacher, 803 S.E.2d at 68.

${ }^{13}$ See id. at 69 (explaining that two cases announcing this rule were inapplicable).

${ }_{15}^{14}$ Schumacher, 803 S.E.2d at 69-71.

${ }^{15}$ See id. at 76-77 (Hines, C.J., dissenting) (discussing the soundness of the precedent's reasoning, the presence or absence of reliance interests, the age of the precedent, and the workability of the precedent "in light of the policy of stare decisis").

${ }^{16} I d$. at 77 (Hines, C.J., dissenting) (“[M]ost importantly in this situation is the factor of workability.").

${ }^{17}$ See id. (Hines, C.J., dissenting) ("There can be little dispute that the bright line rule . . . has provided needed clarity and direction to the bench and bar in the all-too-often quagmire of appellate procedure.").

${ }^{18}$ Id. at 74 (Hines, C.J., dissenting) (citing O S Advertising Co. v. Rubin, 482 S.E.2d 295, 296 (1997)). 
"decision of an administrative agency." "19 Nevertheless, the dissent was adamant that "the doctrine of stare decisis strongly counsels adherence to our . . . workable precedents."20

The dissent's argument that an erroneous but "eminently workable"21 interpretation should be retained for the sake of judicial convenience gives rise to a serious separation of powers concern. ${ }^{22}$ Not only would this infringe on the domain of the legislature, but it would also circumvent the legislative process entirely by removing the legislature's most meaningful incentive to act. This Note will focus on exploring this concern. It must first be recognized, however, that the dissent's argument draws on a line of decisions by the Supreme Court of the United States for its support. ${ }^{23}$ For proper context, therefore, this Note turns initially to that history.

\section{A. The Rise of Workability as a Stare Decisis Consideration}

Compared to the doctrine of stare decisis, workability is a fledgling concept. ${ }^{24}$ Federal courts did not speak of precedent in terms of workability until the United States Supreme Court did so in 1965 in Swift \& Co. v. Wickham. ${ }^{25}$ State courts had begun to incorporate this factor a few years earlier. ${ }^{26}$ In Swift, the Court reconsidered its interpretation of a federal statute,

${ }^{19}$ GA. CoDE. ANN. § 5-6-35(a)(1); supra note 11.

${ }^{20}$ Schumacher, 803 S.E.2d at 74, 78 (Hines, C.J., dissenting).

${ }^{21} \mathrm{Id}$. at 77 (Hines, C.J., dissenting).

${ }^{22}$ See id. at 76-77 (Hines, C.J., dissenting) (contending that the bright-line rule should have been retained because it "promot[ed] judicial management and economy" and removed all "doubt for trial courts, practitioners, and indeed, litigants as to the proper procedure for an appellate challenge of a zoning issue").

${ }^{23}$ See infra notes 75-76 and accompanying text.

${ }^{24}$ See generally Frederick G. Kempin, Jr., Precedent and Stare Decisis: The Critical Years, 1800 to 1850, 3 AM. J. LEgAL HIST. 28 (1959) (describing how the doctrine of stare decisis began to develop in the United States in the early- to mid-nineteenth century).

${ }^{25} 382$ U.S. 111 (1965).

${ }^{26}$ See, e.g., Conrad v. Conrad, 153 So.2d 635, 639 (Ala. 1963) (Harwood, J., concurring specially) ("The writer does not adhere to the view that stare decisis envisions the perpetrations of erroneous and unworkable legal ipse dixits ...."); Williams v. Detroit, 111 N.W.2d 1, 23 (Mich. 1961) (Edwards, J., dissenting) ("But stare decisis in its most rigorous form does not prevent the courts from correcting their own errors, or from establishing new rules of case law when facts and circumstances of modern life have rendered an old rule unworkable and unjust."); 
28 U.S.C. $§ 2281$, which mandated empanelment of a three-judge panel whenever a litigant in federal court sought to enjoin enforcement of a state statute "upon the ground of the unconstitutionality of such statute." ${ }^{27}$ According to the Court, early decisions had treated Supremacy Clause cases as falling outside the purview of $\S 2281$, reasoning that such cases involve no claim that the state law inherently violates the Constitution of the United States, but instead only a claim that the state law conflicts with a federal statute and therefore, according to the Constitution, is preempted. ${ }^{28}$ Contrastingly, in a case decided three years before Swift, Kesler v. Department of Public Safety, the Court had held that a claim of statutory preemption under the Supremacy Clause was a "constitutional question" within the meaning of $\S 2281$, rather than a question of statutory interpretation that could be addressed by a single judge. ${ }^{29}$ Yet, "[a]fter what can only be characterized as extensive statutory analysis . . . the majority [in Kesler] concluded that there had in fact been no pre-emption." 30 To summarize, the Court in Kesler performed some seventeen reporter pages of statutory analysis leading to the conclusion that the state statute was not in conflict with the federal statute, ${ }^{31}$ yet pronounced that the case did not involve a question of statutory construction amenable to adjudication by a single judge. ${ }^{32}$

Landgraver v. Emanuel Lutheran Charity Bd., 280 P.2d 301, 317 (Ore. 1955) (Brand, J., dissenting) ("The recent decisions convincingly demonstrate that the immunity doctrine is unsound and unworkable.").

27382 U.S. at 114 (quoting 28 U.S.C. 2281 (1958 ed.)).

${ }^{28}$ Id. at $120-22$ (citations omitted).

${ }^{29}$ The Court was emphatic on this point:

Here, no question of statutory construction, either of a state or a federal enactment, is in controversy. We are confronted at once with the constitutional question whether [a State police power is preempted]. . . . This case presents a sole, immediate constitutional question, differing from [previous cases] which presented issues of statutory construction even though perhaps eventually leading to a constitutional question.

Kesler v. Dep't of Pub. Safety, 369 U.S. 153, 157-58 (1962).

${ }^{30}$ Swift, 382 U.S. at 123 (citing Kesler, 369 U.S. at 158-74).

${ }^{31} 369$ U.S. at $158-74$.

${ }^{32} I d$. at $157-58$. This conclusion is not inherently unreasonable. It is certainly true that preemption cases involve a "constitutional question" and the Court could have construed $\S 2281$ to include all preemption cases. Instead, the Court appeared to hold that some preemption cases could fall outside the scope of $\S 2281$, leading to confusion. See infra note 36. 
Thus, when the lower court in Swift had been faced with the question of whether New York's poultry labelling law was pre-empted by the federal Poultry Products Inspection Act of $1957,{ }^{33}$ it was understandably confused. ${ }^{34}$ Was there a "question of statutory construction, either of a state or a federal enactment . . . in controversy," 35 or was this a "constitutional question" of the sort in Kesler ${ }^{36}$ The Kesler rule was unworkable, the Supreme Court concluded, and therefore stare decisis did not compel the Court to retain it:

Unless inexorably commanded by statute, a procedural principle of this importance should not be kept on the books in the name of stare decisis once it is proved to be unworkable in practice; the mischievous consequences to litigants and courts alike from the perpetuation of an unworkable rule are too great. ${ }^{37}$

Throughout the five decades since Swift, members of the Court have regularly argued for reexamining statutory decisions on grounds that they had proven unworkable. ${ }^{38}$ The Court has

${ }^{33}$ Swift, 382 U.S. at 112; 21 U. S. C. $\S \S 451-69$ (1964 ed.)

${ }^{34}$ Swift, 382 U.S. at $114-15$.

${ }^{35}$ Kesler, 369 U.S. at 157.

${ }^{36}$ The Kesler rule left it unclear when, if ever, a preemption case could be adjudicated by a single judge. The Court in Swift appeared to understand the Kesler rule to mean that whether three judges must be empaneled depended on whether a determination would require more or less statutory construction than had occurred in Kesler:

[T] he District Court was quite right in concluding that the question of a three-judge court turned on the proper application of our 1962 decision in Kesler v. Department of Public Safety, 369 U.S. 153. There we decided that in suits to restrain the enforcement of a state statute allegedly in conflict with or in a field pre-empted by a federal statute, $\S 2281$ comes into play only when the Supremacy Clause of the Federal Constitution is immediately drawn in question, but not when issues of federal or state statutory construction must first be decided even though the Supremacy Clause may ultimately be implicated. Finding itself unable to say with assurance whether its resolution of the merits of this case involved less statutory construction than had taken place in Kesler, the District Court was left with the puzzling question how much more statutory construction than occurred in Kesler is necessary to deprive three judges of their jurisdiction. Swift, 382 U.S. at 115.

${ }^{37} I d$. at 116.

${ }^{38}$ See, e.g., Johnson v. United States, 135 S. Ct. 2551, 2562 (2015) ("The doctrine of stare decisis allows us to revisit an earlier decision where experience with its application reveals that it is unworkable. . . Here, the experience of the federal courts leaves no doubt about the unavoidable uncertainty and arbitrariness of adjudication under the residual clause.”); Altria Group, Inc. v. Good, 555 U.S. 70, 92, 96-98, 108 (2008) (Thomas, J., dissenting) (arguing that the Court should have rejected an "ill-conceived" and "unworkable" approach to deciding Labelling Act pre-emption cases in favor of a "far more workable and textually sound" test); Clark v. Suarez Martinez, 543 U.S. 371, 402 (2005) (Thomas, J., dissenting) ("we should not hesitate to allow our precedent to yield to the true meaning of an Act of Congress when our statutory precedent is 'unworkable' or 'badly reasoned."'); Holder v. Hall, 512 U.S. 874, 936 (1994) (Thomas, J., concurring) (“[Our errors] have produced an 'inherent tension' between our interpretation of [the Act] and the text of the Act and have yielded a construction of the statute that ... is so unworkable in practice and destructive in its effects that it must be repudiated"); United States v. Johnson, 481 U.S. 
expressed no second thoughts about using the workability factor as a weapon against pernicious precedent, but rather has standardized such usage: "[T]he fact that a decision has proved 'unworkable' is a traditional ground for overruling it." 39 "[W]hen governing decisions are unworkable or badly reasoned, 'this Court has never felt constrained to follow precedent.,"40 Indeed, the Court did not confine this inquiry to statutory cases, but integrated the workability inquiry into constitutional jurisprudence as well; the inquiry was central to the Court's decision to overturn precedent in prominent cases such as Arizona v. Gant ${ }^{41}$ and Garcia v. San Antonio Metropolitan Transit Authority. ${ }^{42}$ In many other constitutional cases as well, the Court has given considerable weight ${ }^{43}$ to arguments that prior rulings had turned out to be unworkable. ${ }^{44}$ The rationale that unworkable precedent should be rejected has been treated as particularly apt in

681, 701-03 (1987) (Scalia, J., dissenting) (opining that stare decisis did not compel the Court to extend an unworkable and incorrect interpretation of the Federal Tort Claims Act); Moragne v. States Marine Lines, 398 U.S. 375, 404-05 (1970) (rejecting, in light of modern statutory remedies, a common-law maritime rule providing no cause of action for wrongful death on the high seas when the death resulted from a vessel's unseaworthiness as producing "litigation-spawning confusion in an area that should be easily susceptible of more workable solutions").

39 Montejo v. Louisianna, 556 U.S. 778, 779 (2009) (quoting Payne v. Tennessee, 501 U.S. 808, 827 (1991)).

${ }^{40}$ Payne, 501 U.S. at 828 (quoting Smith v. Allwright, 321 U.S. 649, 665 (1944)).

${ }^{41}$ Arizona v. Gant, 556 U.S. 332, 338-40 (2009) (revisiting the rule in New York v. Belton because "courts ha[d] found no workable definition of 'the area within the immediate control of the arrestee' when that area arguably includes the interior of an automobile") (quoting New York v. Belton, 453 U.S. 454, 460 (1986)).

${ }^{42}$ Garcia v. San Antonio Metro. Transit Auth., 469 U.S. 528, 546-47 (1985) ("We therefore now reject, as unsound in principle and unworkable in practice, a rule of state immunity from federal regulation that turns on a judicial appraisal of whether a particular governmental function is 'integral' or 'traditional."')

${ }^{43}$ It is not unusual for the Court to provide several reasons for overruling precedent: "Indeed, in one form or another, most Justices throughout history have favored overruling precedents on the grounds of erroneous reasoning and some other serious flaw justifying overruling, including unworkability and inconsistencies with case law." Michael J. Gerhardt, The Role of Precedent in Constitutional Decisionmaking and Theory, 60 GEO. WASH. L. REV. 68, 145 (1991).

${ }^{44}$ See, e.g., Montejo, 556 U.S. at 792, 797 (overruling Michigan v. Jackson, 475 U.S. 625 (1986), in part as "unworkable in more than half the States of the Union"); FEC v. Wis. Right to Life, Inc., 551 U.S. 449, 500-04 (2007) (Scalia, J., concurring); United States v. Dixon, 509 U.S. 688, 709-12 (1993) (overruling the double jeopardy test of Grady v. Corbin, 495 U.S. 508 (1990), as "wrong in principle" and "unstable in application"); Webster v. Reprod. Health Servs., 492 U.S. 490, 518 (1989) ("We have not refrained from reconsideration of a prior construction of the Constitution that has proved 'unsound in principle and unworkable in practice.' . . We think the Roe trimester framework falls into that category.") (citations omitted); City of Akron v. Akron Ctr. for Reprod. Health, 462 U.S. 416, 459 (1983) (O’Connor, J., dissenting) ("[The Roe trimester] framework is clearly an unworkable means of balancing the fundamental right and the compelling state interests that are indisputably implicated."). 
constitutional cases, "because in such cases "correction through legislative action is practically impossible.",45

Since Swift, application of the workability factor has transcended personal judicial philosophy and legal context. While members of the Court have not always agreed on whether challenged rules or interpretations had, in fact, produced "mischievous consequences," 46 there appears to be a well-established consensus that "precedents that have proved cumbersome and unpredictable ... [and that] create byproducts of uncertainty, cost, and opacity that all judges can recognize as undesirable" ${ }^{47}$ may be attacked as unworkable. Nevertheless, toward the turn of the century, the workability inquiry began to take on a new function: that of supporting workable precedent.

\section{B. Casey and Recent Approaches}

In two opinions issued in the 1980s, Arizona v. Rumsey ${ }^{48}$ and Patterson v. McLean Credit Union $^{49}$ the Court began to speak of "special justification[s]" for overruling precedent. ${ }^{50}$ Without special justification such as an "intervening development in the law" or "inherent

\footnotetext{
${ }^{45}$ Payne, 501 U.S. at 828 (quoting Burnet v. Coronado Oil \& Gas Co., 285 U.S. 393, 407 (1932) (Brandeis, J., dissenting)).

${ }^{46}$ Swift, 382 U.S. at 116; see, e.g. Gant, 556 U.S. at 360-61 (Alito, J., dissenting) (opining that the Court's new rule would be considerably more problematic than the Belton rule); Wis. Right to Life, 551 U.S. at 535 (Souter, J., dissenting) (contending that, contrary to the majority's analysis, no "serious argument [can] be made that [applicable precedent] has been "unworkable in practice."'); Dixon, 509 U.S. at 759-60 (Souter, J., dissenting) (disagreeing with the majority's stare decisis analysis of the rule in Grady v. Corbin, 495 U.S. 508 (1990), believing that rule was "straightforward"); see also William S. Consovoy, The Rehnquist Court and the End of Constitutional Stare Decisis: Casey, Dickerson and the Consequences of Pragmatic Adjudication, 2002 UTAH L. Rev. 53, 76 (2002) ("Workability is a factor that the Court usually deals with up front, most likely because its inclusion in the Court's stare decisis framework has met with little resistance. . . Although the Justices often disagree intensely about whether a particular rule is workable . . ., no Justice of the current Court has disputed the relevance of workability to the stare decisis analysis.").

${ }^{47}$ Randy Kozel, Stare Decisis in the Second-Best World, 103 CAL. L. Rev. 1139, 1162 (2015).

${ }^{48} 467$ U.S. 203 (1984).

${ }^{49} 491$ U.S. 164 (1989).

${ }^{50}$ Rumsey, 467 U.S at 212.
} 
confusion created by an unworkable decision," a prior decision should stand. ${ }^{51}$ This aggregation of conventional justifications for overruling precedent into one standardized test subtly altered the unworkability inquiry. Previously, unworkability was a condition implying that precedent should be overruled, a status in which the law could not remain. The Court's articulation was almost syllogistic_-if a questionable decision has proven unworkable, then it should be overruled. ${ }^{52}$ The demonstrated unworkability of a ruling was like a warning flag, and accordingly the Court paid attention to it only if it was present. Now, unworkability became a box to be checked, a consideration to be addressed whenever stare decisis is implicated. ${ }^{53}$ Suddenly, as a consequence, the Court began upholding decisions as not unworkable. ${ }^{54}$ The first few decisions to do so, however, included very little discussion of workability, and in only one of them was there any serious contention that the underlying rule was wrong. ${ }^{55}$ Thus, they are not particularly

51 Patterson, 491 U.S. at 173 (noting further that " $[\mathrm{t}]$ he burden borne by the party advocating the abandonment of an established precedent is greater where the Court is asked to overrule a point of statutory construction.").

${ }^{52}$ There is some disagreement about when stare decisis is implicated. Some jurists believe that stare decisis becomes relevant only when a decision is wrong in the first place. E.g., George v. Hercules Real Estate Servs., 795 S.E.2d 81, 90 (Ga. Ct. App. 2016) (Peterson, J., concurring) ("[T]he principle of stare decisis does not even begin to apply until we have already concluded that a prior decision was wrong."). Sometimes courts look to stare decisis even though they believe precedent is correct as additional support for their refusal to overrule that precedent, or without even reaching an initial determination via other interpretative means. See, e.g., Richlin Sec. Serv. Co. v. Chertoff, 553 U.S. 571, 590 (2008) ("[T]raditional tools of statutory construction and considerations of stare decisis compel the conclusion [in this case] . ...”); Patterson, 491 U.S. at 171-72 (affirming by reason of stare decisis the Court's prior ruling that 42 U.S.C. $\$ 1981$ prohibits racial discrimination in the making and enforcement of private contracts without attempting to resolve the Court's previous split as to that interpretation). A court may look to stare decisis whenever precedent is challenged. See State v. Fremgen, 914 P.2d 1244, 1245 (Alaska 1996) ("When a common law court is asked to overrule one of its prior decisions, the principle of stare decisis is implicated."). The stare decisis analysis can also be used as evidence that precedent was incorrect to start with, as in Swift. In any event, all cases in which stare decisis arises are cases in which the soundness of a rule or interpretation has been called into question. Whether the decision is questionable because unworkable or whether it was initially questioned for some other reason makes no difference for purposes of the above analysis.

${ }^{53}$ Allied-Signal, Inc. v. Dir., Div. of Taxation, 504 U.S. 768, 783 (1992) ("One relevant consideration is whether the decision is . . 'unworkable in practice."') (citations omitted).

${ }^{54}$ See id. at 785 (“Our precedents are workable in practice ...."); California v. FERC, 495 U.S. 490,499 (1990) ("There has been no sufficient . . . indication that [applicable precedent] has proved unworkable or has fostered confusion and inconsistency in the law, that warrants our departure from established precedent"); Patterson, 491 U.S. at 173-74 (1989) (“[W]e do not find [applicable precedent] to be unworkable or confusing.").

${ }^{55}$ In Patterson, the Court mentioned that some members of the Court believed the challenged precedent was wrongly decided, but gave no opinion on whether it was so, opting instead to uphold it in the name of stare decisis. 491 U.S.at 171-75. The dissent believed that the applicable precedent had been correctly decided and that 
strong authority for any proposition related to stare decisis. They did, however, set the stage for the Court's next explication of stare decisis in Planned Parenthood v. Casey. ${ }^{56}$

In Casey, a majority of the Court fully embraced this new discrete-inquiry approach to workability. ${ }^{57}$ The Court cited Swift and Payne, but departed from their reasoning-namely, that when precedent has proven unworkable it should be rejected-by interpreting them as suggesting a "prudential and pragmatic" approach to stare decisis:

[W]hen this Court reexamines a prior holding, its judgment is customarily informed by a series of prudential and pragmatic considerations designed to test the consistency of overruling a prior decision with the ideal of the rule of law, and to gauge the respective costs of reaffirming and overruling a prior case. Thus, for example, we may ask whether the rule has proven to be intolerable simply in defying practical workability....58

It hardly requires mentioning that in Casey the question of whether the underlying rule (from Roe v. Wade) ${ }^{59}$ was correct as a matter of law was strongly contested by the parties and sharply divided the Court. Because of the "weight of the arguments made on behalf of the State... which in their ultimate formulation conclude that Roe should be overruled," the outcome would depend in large part on whether stare decisis mandated retention of that

Congress had since ratified it. Id. at 191. In California v. FERC, although the Court opined that the challenged precedent was not unworkable, its decision not to overrule its previous interpretation appeared to rest primarily on other grounds, including reliance interests and Congressional ratification. 495 U.S. at 498-500. Finally, in AlliedSignal, the State did not contend that the underlying rule (the "unitary business principle," which at the time was a nearly one-hundred-year-old doctrine circumscribing a state's power to tax interstate corporations) was wrong as a matter of constitutional law, but only that it did not "reflect economic realities" and should be abandoned. 504 U.S. at $777-84$.

${ }^{56} 505$ U.S. 833 (1992). It should be noted that Casey and Allied-Signal were decided the same year, only two years after California v. FERC and only three years after Patterson. See supra note 54. Justice Kennedy delivered the opinion of the Court in Patterson; Chief Justice Rehnquist and Justices White, O'Connor, and Scalia joined his opinion. In California v. FERC, Justice O'Connor delivered the unanimous opinion. Justice Kennedy delivered the majority opinion in Allied-Signal, and was again joined by Justices White and Scalia; Justices Steven and Souter joined to create a majority of five. In Casey, Justices O'Connor, Kennedy, and Souter announced the opinion as to Part III (concerning stare decisis and workability); Justices Blackmun and Stevens joined as to that portion.

${ }_{58}^{57}$ Five justices joined this part of the opinion. Supra note 56.

${ }^{58}$ Casey, 505 U.S. at 854 (emphasis added). This question reflects the discretized search for special justifications described supra in text accompanying notes 48-53.

${ }^{59} 410$ U.S. 113 (1973). 
precedent. ${ }^{60}$ Looking first to workability, the majority concluded that "[a]lthough Roe has engendered opposition, it has in no sense proven 'unworkable,' representing as it does a simple limitation beyond which a state law is unenforceable. ${ }^{.61}$ This conclusion ultimately supported the Court's decision to retain the basic holding of Roe. ${ }^{62}$

Since Casey, the Court has used workability both as a sword and a shield. The Court has continued to strike down pernicious precedent under the rationale of Swift and Payne, but by now, shielding precedent as "not unworkable" per Casey's discrete-inquiry approach seems almost instinctive. ${ }^{63}$ The ambiguities introduced into the stare decisis analysis by Casey have been widely criticized. ${ }^{64}$ For one thing,

The workability inquiry, which asks whether a line of decisions supplies reasonably clear criteria susceptible of principled, predictable judicial application, itself fails to do so, but instead has degenerated into an ad hoc gestalt judicial inquiry, capable of being applied in either direction depending on the Court's preferences. That is precisely what the doctrine, as formulated, says is not the objective. $^{65}$

${ }^{60}$ See Casey, 505 U.S. at 853, 870, 912, 923-24 (various opinions stating that the decision depended largely on stare decisis). An alternative and substantive rationale was based on concepts of individual liberty. Id. at 846-53.

${ }^{61} I d$. at 855 (emphasis added).

${ }^{62} I d$. at $870-71$.

${ }^{63}$ See, e.g., Kimble v. Marvel Entm't, LLC, 135 S. Ct. 2401, 2404 (2015) (“[N]othing about [our prior decision] has proved unworkable."); Boumediene v. Bush, 553 U.S. 723, 842 (2008) (Scalia, J., dissenting) ("The rule that aliens abroad are not constitutionally entitled to habeas corpus has not proved unworkable in practice ....”); United States v. Balsys, 524 U.S. 666, 712 (1998) (Breyer, J., dissenting) ("What is more, there is no suggestion that Murphy's rule, applied to state and federal prosecutions, 'has proven intolerable simply in defying practical workability."'); Allied-Bruce Terminix Cos. v. Dobson, 513 U.S. 265, 284 (1995) (O'Connor, J., concurring) ("Though wrong, [our previous interpretation of the Federal Arbitration Act] has not proved unworkable....."); United States v. Dixon, 509 U.S. 688, 741 (1993) (Blackmun, J., concurring in part and dissenting in part) ("I also share both [Justice Souter] and Justice White's dismay that the Court so cavalierly has overruled a precedent that is barely three years old and that has proved neither unworkable nor unsound.").

${ }^{64}$ See, e.g., Consovoy, supra note 46, at 84 ("One of the justifications for granting certiorari to Casey in the first place was the confusing and inconsistent application of Roe in the nineteen years since its announcement. Moreover, it remains unclear why such a workable doctrine mandated an abandonment of the very framework underlying its holding."); Symposium, Precedent \& the Roberts Court: Perspectives on the Doctrine of Stare Decisis, 86 N.C.L. REV. 1165, 1201 (2008) ("[T]he Court's doctrine about precedent fails its own test(s) of when precedents should be adhered to. Indeed, the doctrine fails all of the doctrine's own tests: It is embarrassingly unworkable."); John Wallace, Stare Decisis and the Rehnquist Court: The Collison of Activism, Passivism and Politics in Casey, 42 Buffalo L. Rev. 187, 236 (1994) (explaining the inconsistency of Casey and Garcia v. San Antonio Metropolitan Transit Authority with respect to workability).

${ }^{65}$ Symposium, Precedent \& the Roberts Court, supra note 64, at 1201. 
Nevertheless, workability in one form or another appears to have some staying power, having now been a favorite tool of the nation's most eminent jurists for over five decades. Such favor tends to indicate that the concept has some merit. Yet, criticisms such as that above have gone unanswered. Perhaps that it is because the essential nature of the problem has gone almost wholly unidentified. ${ }^{66}$

\section{ThE RIGHT AND WRONG WAY TO APPLY WORKABILITY}

In this section, this Note will discuss what the author believes is the central flaw in Casey's transformation of the workability factor. ${ }^{67}$ Once this flaw is identified and explained, it will become apparent that using workability to uphold erroneous precedent is unnecessary as a matter of law and unwise as a matter of practice.

\section{The Casey Fallacy}

As mentioned above, Swift stands for the proposition that if erroneous precedent has proven unworkable, then it should be discarded. ${ }^{68}$ Purporting to apply this rule, the Court in Casey actually committed a textbook example of the formal fallacy of denying the antecedent:

${ }^{66}$ For the sole exception that it has been possible to locate, see infra note 69 and accompanying text.

67 Throughout, the author has endeavored to avoid injecting any judgment, favorable or unfavorable, regarding the substance or merits of any of the cases cited because the purpose of this Note is not to argue for a test that produces particular outcomes, but rather for a test that is not itself seriously flawed from a jurisprudential standpoint. Furthermore, the author recognizes that many of these cases involve complex and controversial moral and cultural matters of pressing importance. By declining to comment on these considerations or to explore how they may have influenced the outcome of any particular case, this Note does not suggest that such inquiries are unmeritorious in the context of stare decisis or any other sense. But the scope of this Note is necessarily quite limited. Thus, when any of the author's own analysis indicates that a case is flawed or rightly reasoned, such suggestion is directed solely toward the proposition for which the case has been invoked. Furthermore, the author has not selected critical analyses from other sources based on the viewpoint they express, but based solely on their analysis of the issue at hand.

${ }^{68}$ For purposes of this article, that is. Of course, other factors such as reliance interests, the age of the precedent, changed circumstances, and whether the precedent is statutory or constitutional, procedural or substantive, and so forth, may also be considered. 
Roe had not proven unworkable; therefore, it should be retained. ${ }^{69}$ In other words, Casey stands for an entirely different proposition than does Swift, namely, that if precedent is not unworkable, then it should not be discarded. ${ }^{70}$

Of course, the Court was entitled to adopt this new, preservative use of workability if it wanted to do so. ${ }^{71}$ But, by implying that its analysis was faithful to the long line of decisions stemming from Swift, the Court gave the new usage a misleading appearance of legitimacy and historical acceptance. As argued below, the Court's mistake of reasoning represented, ironically, a regrettably imprudent departure from well-settled law. It created a rule that is exceptionally dangerous to the structural integrity of government.

\section{The Dangerous Consequence}

For the sake of simplicity, this Note has largely ignored other stare decisis considerations addressed in Casey and other cited decisions. For example, the majority in Casey leaned rather heavily on the suppositions that for twenty years American culture had been shaped by reliance on the availability of abortion and that neither the law nor other circumstance had changed in a

\footnotetext{
${ }^{69}$ Professor Michael Stokes Paulsen has previously recognized the presence of this fallacy in Casey: The inquiry into "workability," as framed by the Court, is essentially a question of whether the Court believes itself able to continue working within a framework established by a prior decision. The unworkability of precedent provides additional incentive for the judiciary to overrule it.

But the converse does not necessarily follow: The mere fact of workability is not a strong argument in favor of retaining a precedent. There may exist multiple "workable" interpretations of a text, but some of them are clearly wrong. A rule that says police may search homes whenever they like, without limitation, is readily judicially administrable ("the government always wins"), as is a rule that the police may never conduct searches ("the government always loses"). But neither one is a sound interpretation of the Fourth Amendment. Workability alone should not validate either one; if a court had lapsed into either error, the fact that the erroneous ruling made for a nice, crisp, bright-line rule surely would not be a sufficient reason to adhere to it.
}

Michael S. Paulsen, Abrogating Stare Decisis by Statute: May Congress Remove the Precedential Effect of Roe and Casey?, 109 YALE L.J. 1535, 1552 (2000).

${ }^{70}$ Again, disregarding other factors for the sake of simplicity.

${ }^{71}$ In the constitutional context, that is. As the Note argues, the Court should not adopt such a usage in the context of statutory interpretation because of the threat to separation of powers. Infra pp. 16-18. 
way that rendered Roe obsolete, among other arguments. ${ }^{72}$ Thus, in Casey, workability was one of many defensive weapons employed by the Court to preserve Roe; it could be argued that it was not even the most important one. Nevertheless, a shield is a shield, and the Court made no attempt to limit its new defensive tactic to constitutional cases or cases where other factors weighed strongly in favor of retaining the precedent.

For these reasons, it is not hard to see how courts could take the next natural step of utilizing workability as the primary shield for precedent of any sort. The dissent in Schumacher is illustrative. The practical superiority of the bright-line interpretation (i.e., the rule directing that appeals in "all zoning cases" were to be discretionary) was, in the dissent's view, the single most important reason for retaining that interpretation, despite that interpretation's marked conflict with the plain meaning of the statute: ${ }^{73}$ " $[\mathrm{M}]$ ost importantly [sic] in this situation is the factor of workability. .. The workability of [the bright-line rule] cannot credibly be questioned." 74 The dissent was not going out on its own limb by taking this approach. It supported its rationale by pointing to the eminent authority of the United States Supreme Court:

Contrary to any claim that the workability of a precedent is not a reason for retaining it, the United States Supreme Court and this Court have held otherwise. In Kimble v. Marvel Entm't, LLC . . , the Supreme Court stated that nothing about the precedent under consideration had proved unworkable; that the decision was "simplicity itself to apply"; that its "ease of use" appeared "in still sharper relief when compared to [the] proposed alternative"; and that the more "elaborate inquiry" would produce higher litigation costs and unpredictable results. The Court determined that it should not trade in a decision which was eminently workable for one with perhaps better legal reasoning but which was not as workable. It concluded that "[o]nce again, then, the case for sticking with longsettled precedent grows stronger. Even the most usual reasons for abandoning stare decisis cut the other way here."

${ }^{72} 505$ U.S. 853, 855-59 (1992).

${ }^{73}$ Supra note 19 and accompanying text; Schumacher v. City of Roswell, 803 S.E.2d 66, 77 (Ga. 2017) (Hines, C.J., dissenting).

${ }^{74}$ Schumacher, 803 S.E.2d at 77 (Hines, C.J., dissenting).

${ }^{75}$ Id. at 77-78 (Hines, C.J., dissenting) (quoting Kimble v. Marvel Entm't, LLC, 135 S. Ct. 2401, 2411 (2015)). 
Contrary, however, to the dissent's own claim, its argument does not effectively answer the central argument against applying workability this way precisely because the authority the dissent cites is itself flawed. The point is not to criticize the dissent's analysis. On the surface, there was nothing wrong with the application of Kimble here. But there was something wrong with Kimble. That decision was one of the Court's latest statutory cases in the Patterson-Casey workability mold, and thus included the hidden fallacy emanating from those cases. ${ }^{76}$

Having shown above why Swift does not necessitate a preservative use of workability, it remains to show why such a use is inappropriate in the statutory context. As the Supreme Court of Michigan has cogently explained,

Although ... the doctrine of stare decisis constitutes "the preferred course because it promotes the evenhanded, predictable, and consistent development of legal principles, fosters reliance on judicial decisions and contributes to the actual and perceived integrity of the judicial process," so also are these values promoted by the separation of powers doctrine, which holds that it is the responsibility of the judiciary to respect the intentions of the Legislature by giving faithful meaning to the words of the law. . . . Not only, in our judgment, are laws generally made more "evenhanded, predictable and consistent" when their words mean what they plainly say, and when all litigants are subject to the equal application of such words, but laws are also made more accessible to the people when each of them is able to read the law and thereby understand his or her rights and responsibilities. When the words of the law bear little or no relationship to what courts say the law means...., then the law increasingly becomes the exclusive province of lawyers and judges. ${ }^{77}$

It must not be forgotten that although as a practical matter courts and legislatures benefit from stare decisis, the people are the ultimate and intended beneficiaries. ${ }^{78}$ The power of stare decisis to make the law knowable is one of the doctrine's primary justifications. ${ }^{79}$ Maintaining

${ }^{76}$ See Kimble, 135 S. Ct. at 2411 (citing Patterson v. McClean Credit Union, 491 U.S. 164, 173 (1989)).

${ }_{77}^{7}$ Garg v. Macomb Cty. Cmty. Mental Health Servs., 472 Mich. 263, 285 n. 10 (2005) (citations omitted).

${ }^{78}$ See Robert Von Moschzisker, Stare Decisis in Courts of Last Resort, 37 HARV. L. REV. 409, 410 (1924) (explaining who benefits from stare decisis and how).

${ }^{79}$ Indeed,

From the very nature of law and its function in society, the elements of certainty, stability, equality, and knowability are necessary to its success, but reason and the power to 
interpretations that fly in the face of statutes' plain text makes the statutes incomprehensible and contravenes the basic purpose of stare decisis—or at least suggests that only judge-made law need be knowable.

In the context of statutory interpretation, the saving grace of stare decisis is that the legislature can change the language of the law if it disapproves of the judiciary's interpretation. ${ }^{80}$ This line of thinking, however, cannot justify preservative use of the workability factor. The reason is simple: using workability to shield incorrect interpretations destroys the legislature's incentive to act. It is one thing for a court to retain a questionable interpretation that has engendered such heavy reliance that overturning it should be left to the legislature as the body better able to weigh the costs and benefits of such action, or to continue applying a well-known rule that is so old the legislature has effectively ratified it. It is quite another to fix a rule prescribed by statute and then expect the legislature to respond. Consider the legislature's options in such a case: it can enact legislation attempting to reinstate the original meaning of the statute; it can change the statute to conform to the judiciary's interpretation; or it can do nothing. In the latter two scenarios, the affront to separation of powers is clear: the legislative will, as expressed by the plain language of the statute, succumbs to the will of the judiciary. The first option seems promising - in fact it seems to reflect that healthy competition that designedly characterizes the relationship between the branches. ${ }^{81}$ But think what the legislature is being

advance justice must always be its chief essentials; and the principal cause for standing by precedent is not to be found in the inherent probable virtue of a judicial decision, it "is to be drawn from a consideration of the nature and object of law itself, considered as a system or a science." Id. at 414 (citation omitted).

${ }^{80}$ See Patterson, 491 U.S. at 172-73 ("Considerations of stare decisis have special force in the area of statutory interpretation, for here, unlike in the context of constitutional interpretation, the legislative power is implicated, and Congress remains free to alter what we have done.").

${ }^{81}$ See ThE Federalist No. 51, at 317-19 (James Madison) (Signet Classic 2003) (describing the competing ambitions of the members of each branch as the "great security against a gradual concentration of the several powers in the same department"). 
asked to do, and it will become apparent that the promise of this solution is illusory. Where is the incentive for the legislature to change a "workable" rule?

"The mere fact that Congress can overturn our cases by statute is no excuse for failing to overrule a statutory precedent of ours that is clearly wrong, for realities of the legislative process often preclude readopting the original meaning of a statute that [the courts] have upset." 82 These realities are numerous and formidable. For starters, is it realistic to expect that the legislature will be so zealous of its rights that it will attempt to vindicate them by reinstating a law that influential constituents (i.e., lawyers) disfavor? The political opportunity that existed at the time the law was initially passed may have been lost. Testimony, studies, and circumstances that supported the law's adoption may have passed out of memory. And what will bring the matter to the legislature's attention? At least in theory, the frustrations experienced by judges and practitioners as they sincerely attempt to apply a functionally defective law would serve to attract the attention of legislators (many of whom typically are attorneys themselves). But these have been wiped away by the judicial fix. Thus, the preservative use of workability shields the erroneous interpretation not only from elimination by the courts but at least somewhat from the eyes of the legislature. This may even forestall discovery of a better solution, and leave the judiciary feeling obligated constantly to reevaluate the practical effects of its decisions. Finally, even if all these problems and others there is not space to address were avoided, it makes little sense for a legislature to enact clear language, have courts invent a supposedly better solution, and then compel the legislature to rethink its previous decision. The potential for abuse is quite clear here.

${ }^{82}$ Clark v. Suarez Martinez, 543 U.S. 371, 402 (2005) (Thomas, J., dissenting). 


\section{CONCLUSION}

This Note has described the genesis and metamorphosis of workability, and highlighted the defect that arose as a result of its transformation. Born of a procedural quagmire, the workability inquiry began its career serving as a weapon to eliminate functionally obnoxious precedent. Initially, courts wielded it only when the occasion called for it. Gradually, courts worked it into their standard arsenal, and it became a regular part of an increasingly discretized stare decisis test. Toward the turn of the millennium, an error of reasoning refashioned workability into a defensive weapon. As such, workability may be uniquely effective but it is also uniquely dangerous, critically compromising the legislative will and burdening courts with a task they were not meant to bear in a way that no other stare decisis factor appears to do. To compound matters, courts' handling of workability has been anything but deft. Decisions applying it in recent decades have lacked clarity, precision, and consistency. They have suffered from flawed logic. This inexpert management imperils the greater good.

Nevertheless, it goes without saying that unworkable rules are a bad thing. ${ }^{83}$ The following formulation could allow workability to remain part of the stare decisis test and continue to fight the good fight while precluding its misapplication:

Definition: A rule or interpretation is unworkable if it is insusceptible of principled, consistent, and predictable application. ${ }^{84}$

${ }^{83}$ Professor Randy Kozel has contended that workability is not an essential part of stare decisis analysis and has criticized application of the factor for creating "intractable disagreements over whether a precedent really is unworkable." Randy J. Kozel, Stare Decisis as Judicial Doctrine, 67 WASH. \& LEE L. REV. 411, 421-25 (2010). But he goes on to point out that

Of course, all else being equal, it is preferable for the Court to choose a workable rule of decision rather than an unworkable one. Unworkable rules are clumsy and unpredictable, creating needless costs and diluting the benefits of a stable society governed by the rule of law. But the reason for favoring workable doctrines is because that is a sensible approach to selecting the rule of decision to govern an area of law. The choice does not reflect any inherent link between a precedent's workability and its claim to deference. Id. at 423 . 
1. If it is contended that an interpretation is unworkable and the court agrees, the court should treat the interpretation's unworkability as evidence that the interpretation is wrong. The court should proceed to reconsider the interpretation. If it is determined that the interpretation is correct based on a principled application of interpretive methods (beginning with examination of the plain language of the statute), the interpretation should be maintained unless by reason of its unworkability the statute is void for vagueness or other reason. ${ }^{85}$

2. If it is contended that an interpretation is unworkable but the court disagrees, the effect of such disagreement should be limited to rejecting the contention. The court's belief that the interpretation is workable should be given no weight as against other considerations that may recommend rejecting the interpretation, nor any weight in addition to other considerations that may recommend retaining the interpretation.

3. If an interpretation is challenged on some other basis but not on grounds that it is unworkable, a court should not inquire sua sponte whether the interpretation is workable. The court should proceed as called upon to consider whether the interpretation is sound and whether other factors weigh in favor of retaining the interpretation in the interests of justice.

It may be contended that this formulation suggests a distinction without a difference.

After all, there seem to be only two possibilities: precedent is either workable or it is not. If a reviewing court does not reject precedent as unworkable, then it retains it as workable, right? Not

${ }^{84}$ This is consistent with the approach in Swift. See Rafael Gely, Of Sinking and Escalating: A (Somewhat) New Look at Stare Decisis, 60 U. PITT. L. REV. 89, 133-34 (1998), for a description of other ways the Court has defined workability.

${ }^{85}$ In such a case, courts would simply have to do their best to apply the law in fair and consistent manner. Notably, even in Swift, where the rule represented the very prototype of unworkability, the Court noted that it could have disposed of the issue without overruling Kesler simply by making a decision regarding the relative amount of statutory interpretation involved. Swift \& Co. v. Wickham, 382 U.S. 111, 115 (1965). Nevertheless, it would be prudent for courts frequently faced with applying a confusing statute to express their dissatisfaction with the law in writing and attempt to provide clear guidance for litigants. The concurrence in Schumacher provides an example of this:

What, for example, is a "decision"? Or an "administrative agency"? And what is the answer when a case raises claims regarding legislative, executive, and adjudicative decisions by a government entity acting in different capacities with respect to each of the "decisions"? The statute invites rather than answers these questions, and we can only do so much to simplify while also remaining faithful to its text.

Accordingly, the General Assembly may wish to clarify the scope of the matters that are subject to the discretionary appeal process. Until then, the best path forward . . . may well be to follow the advice of two leading Georgia appellate treatises and file a discretionary application in every instance where there is any doubt.

803 S.E.2d 66, 72-73 (Ga. 2017) (Grant, J., concurring). Between this approach and the availability of measures such as declaring a law void for vagueness, courts should be able to fulfill their "institutional responsibility to ensure a workable and just litigation system," Jerman v. Carlisle, McNellie, Rini, Kramer \& Ulrich, L.P.A., 559 U.S. 573, 612 (2010) (Kennedy, J. dissenting), insofar as it lies within their power and authority to do so. 
exactly. Workability is not, in fact, a binary characteristic. One rule might be more workable than another, but both might have some "mischievous consequences." Similarly, one rule might be "eminently workable," but that does not mean every alternative is dysfunctional. In a sense, characterizing a rule as "not unworkable" is to characterize it as anything other than intractable_-such as mediocre, for instance. Is a thing's mediocrity a reason for keeping it? Similarly, to characterize a rule as "eminently workable" is to say that there may remain reasonably workable-even completely satisfactory-alternative rules. The formulation suggested above contemplates all these possibilities and would enable courts to undo errors of their own making while limiting the good-faith bases for retaining questionable interpretations to those that do not have a natural tendency to undermine separation of powers. 